\title{
TEACHING AFRIKAANS AS EMANCIPATORY DISCOURSE
}

\author{
Jeanoe Maartens \\ Department of Afrikans \& Nederlands \\ University of Natal (Durban)
}

\section{ATTIUUDES TOWARDS AFRIKAANS}

There is not a teacher of Afrikaans as second language (L2) in South Africa to-day who does not face an attitude problem in his/her classroom, especially at secondary and tertiary level. Antagonism of a socio-political origin is to be expected from mother tongue speakers of the indigenous languages and from Indian students who are mostly English first language speakers ${ }^{2}$. Surprisingly however, teachers report ${ }^{3}$ a dauntingly derisive attitude from white English speakers - an attitude that the students are often loathe to admit to, never question and can seldom adequately explain ${ }^{4}$. This attitude is clearly reflected in a letter to the Daily News, one of two major daily English newspapers in Natal, on 4 March 1994:

\section{Brush up the Afrikaans commentary}

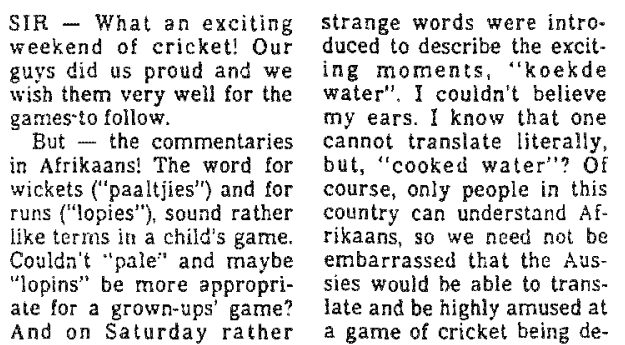

scribed as "cooked water".

It's as bad as the Afri. katis word for a golfer's caddie, "jokkie". And the chap that rides horses is also a "jokkie". Where's the con. nection?

In not knocking the language but I wish the Afri= kaans academics would invent some imaginabive but reasonable tcanslations.

(Mrs) B. le MAITPE Morningsida

For the teacher the situation is compounded by a dismissive attitude from colleagues and administrators as a consequence of uncertainty about the status of Afrikaans in a new dispensation, an attitude eloquently verbalized in another letter to the Daily News towards the end of 1993 : 


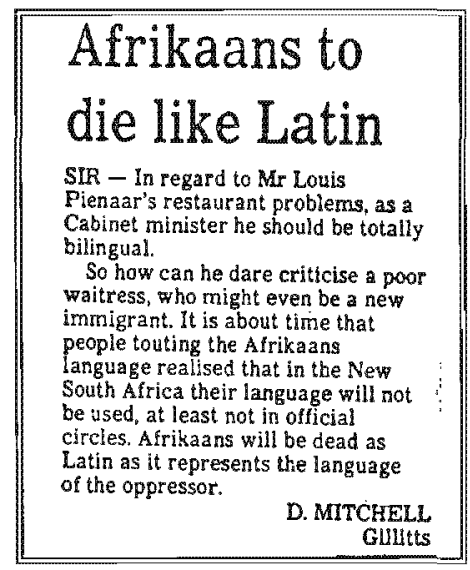

The result is a negativism which leaves many Afrikaans $L 2$ teachers disempowered and disenchanted ${ }^{3}$. Such attitudes are also likely to affect the students' performance in Afrikaans, attitude being widely accepted ${ }^{6}$ as one of the key social-psychological factors in successful second language acquisition. Larsen-Freeman and Long (1992:183) refer to Le Mahieu (1984) for a scheme that represents a vicious circle for the negative L2 learner of Afrikaans:

$\begin{array}{lll}\text { Variance in } & \text { cause } \ldots-> & \text { Variance in } \\ \text { attitudes } & <\cdots \text { cause } & \text { L2 proficiency }\end{array}$

\section{A ROLE FOR CRITICAL LINGUISTICS}

In this situation one of the main tasks of the language teacher should be to help Afrikaans L2 leamers to question their stereotyped attitudes and those of the people around them in a changing context. It is a central tenet of this paper that work done in critical linguistics has a role to play in, among others, accessing alternative perspectives for $L 2$ learners of Afrikaans. In exploring this tenet, I draw heavily on an article by Janks and Ivanic (1992): Critical Language Awareness and Emancipatory Discourse in which they offer an interesting perspective on the role of critical linguistics in language teaching. The research 
1 wish to refer to centres on two key concepts, viz. critical language awareness and emancipatory discourse.

The term language awareness refers, generally, to a conscious attention to the properties of language and language use as an element of language education and specifically, since the early ' $80^{\prime}$ 's, to a movement by a group of language professionals to introduce such a component in the British school curriculum ${ }^{8}$. Critical language awareness (CLA), according to Fairclough (1992:14), would entail "approaching the important issues of language awareness from a critical view of language, highlighting how language couventions and language practices are invested with power relations and ideological processes which people are often unaware of." McKenzie (1992:225) describes CLA as "an attitude of critique towards and scrutiny of the meanings in language and discourse that are propagated by dominant groups and often accepted without question by subordinate groups". Along the same lines Lancaster and Taylor (1992:256) argue that critical language studies enable students "to develop an explicit understanding (= CLA - J.M.) of themselves as language users in the society in which they live". For Janks and Ivanic (1992:305) this explicit understanding includes a consciousness of "how language can be patronizing, demeaning, disrespectful, offensive, exclusive, or the opposite".

1 wish to argue that by leading Afrikaans L2 learners to develop an explicit and critical understanding of thernselves as language users in the South African society, the teacher can bring about a remarkable change of attitude in his/her students. To substantiate such a clain, I wish to share my experiences in teaching Afrikaans as a second language to multiculural and multilingual groups of undergraduate students at the University of Natal (Durban) over the past two years. My findings are borne out by a number of senior Afrikaans teachers doing a course-work Masters in Teaching Afrikaans as a Second Language at UN, who are experimenting with this approach in their classrooms.

Janks and Ivanic (1992:307) see CLA as a "first step" towards the realization that there are "underdogs" language-wise who need "liberation". The second step follows when "awareness is turned into action " and people consciously start contesting the subjection of themselves and 
others through language. In contesting the practices which disempower themselves and others, their discourse becomes emancipatory. Emancipatory discourse then, is discourse that resists disempowerment but also discourse that does not disempower others. In the rest of this paper I will approach the teaching of Afrikaans as L2 from these two points of departure.

\section{TEACHING AFRIKAANS AS EMANCIPATORY DISCOURSE}

\subsection{The L2 learner and discourse that does not disempower}

In teaching Afrikaans as emancipatory discourse to L2 learners, my emphasis at the outset is on creating an awareness that language can and is used to disempower others. In keeping with the recommendation by Janks and Ivanic (1992:320), the CLA part of the course is not taught separately, but rather forms the orientation or approach to the language development part of the course. A general discussion, for example, of how language is used to subject others through being patronizing or demeaning or exclusive is easily integrated with a lecture on word order in Afrikaans by a careful choice of examples. Students enjoy being actively involved by illustrating with examples from their mother tongue. Social responsibility in language use is addressed, especially with reference to groups of people who are powerless and/or stigmatized such as the handicapped, women, homosexuals and ethnic minorities. Appellations such as "kaffir", "native", "non-European", "non-white", "Bantu", "African" and "black", the sensitivity of which most students are aware of, are discussed. The more oblique, and therefor more dangerous, use of language to stereotype and disempower through rnechanisms such as euphernism (e.g. Third World driver) and metaphor (e.g. the Iron Lady) is illustrated from the media. ${ }^{9}$ The students are encouraged to turn awareness into action by actively eradicating such offensive and disempowering language from their own spontaneous use and to adopt language that recognizes the identities and values of others.

The focus then moves to Afrikaans specifically. The goal is to create awareness of the fact that not only are there derogatory and disempowering terms, expressions and images which 
should be avoided when speaking Afrikaans, but also when speaking about Afrikaans and the Afrikaner. The overtly offensive appellations can be divided into two categories:

(i) derogatory English terms such as Dutchran/Dutchies, rocks, rockspider, Valies, Hertzogite and talking code;

(ii) Afrikaans expressions that are used derogatively in English such as boer, A frikaner, taal/taalijie/dic taal and die volk.

In an effort to encourage both awareness and active avoidance of similar practices, letters to the piess such as the two included in this paper are analyzed. Fact can then be separated from what is simply an expression of attitude, based on stereotyped views and misinformation. Attention is drawn to the fact that terms such as embarrassed and highly amused may express an attitude directly, but that this can also be done in a more covert fashion by using linguistic mechanisms such as the diminutive (taaltjie, volkie) to minimize and ridicule. Imagery commonly used in referring to Afrikaans implying that the language is human (Afrikaans is alive and well; Afrikaans to die like Latin) or involved in a war (Atrikaans survives in Argentina; Tyd om met die taal in te grawe) is deconstructed along the lines of Bolinger (1980) and Lakoff \& Johnson (1980). This facilitates the examination of the full and often negative implications. A further topic for discussion in this regard concerns the issue of language choice as a tool for subjection. Afrikaans speakers are regularly disempowered by the refusal of English speakers to switch to Afrikaans in any given siuation - the Afrikaans speaker is always expected to switch to English. Well-meaning invitations to speak Afrikaans even although the others continue speaking English, leave the Afrikaans speaker feeling patronized.

In advocating discourse that does not disempower others, the following paragraph from Janks and Ivanic (1992:313) bears repetition: 
"People sometimes object ... on the ground that attitudes need changing and then language will look after itself. But educators cannot just sit back and wait for attitudes to change: they need to help leamers to question their attitudes and to gain access to alternative perspectives. ... (Emancipatory discourse - J.M.) is a particularly important practice, since language shapes attitudes ... and is in turn shaped by them."

\subsection{The learner and discourse that resists disempowerment}

Instilling in Afrikaans L2 learners an awareness of the need for social responsibility in discourse in and about Afrikaans is only part of teaching Afrikaans as emancipatory discourse. Emancipatory discourse, according to Janks and Ivanic (1992:315) is also discourse that resists disempowerment by "not letting our own needs be neglected, not allowing ourselves to be effaced". Viewing Afrikaans from this perspective is often a totally new experience for the student.

A discussion of language rights as a fundamental human right, ensconced in the new Bill of Rights for South Africa, leads to an exploration of the language rights of Afrikaans speakers, either as first or second language users. As a rule the speakers of English report that they would never use Afrikaans towards an Afrikaans speaking person in the company of English speaking peers, for fear of ridicule. Statements by Afrikaans speakers that they feel too embarrassed to insist on their language rights in any given situation are studied, as well as the type of reaction such action is likely to meet with. I usually put forward for comment views such as those of the Dutch journalist Lydia Lijkendijk in Die Burger ${ }^{10}$ of 15 February 1993 who refers to "... een levensgroot Afrikaans-talig minderwaardigheids - complex" and who comes to the conclusion that "In Zuid-Afrika gelooft zelfs de Afrikaanstalige blijkbaar niet meer in zija eigen taal." She bases these judgements on, for example, the lack of Afrikaans sub-titles to English news items on television, where all Afrikaans items carry English sub-titles. She also refers to the strong tendency among Afrikaans speakers to address all strangers in English. It is interesting that the Afrikaans second language learners 
invariably report feeling disempowered by the Afrikaans habit of switching to English when hearing Afrikaans spoken with an English accent.

Teaching Afrikaans as emancipatory discourse entails encouraging the L.1 as well as the L2 speaker of Afrikaans to develop the self-assurance to speak up, even in situations where he/she feels dominated: the second language learner in the Afrikaans class, the Afrikaans speaker in a meeting or an interview. To this end the possibilities are explored for contesting practices that silence the speaker of Afrikaans and denies him/her a voice. Janks and Ivanic (1992:321ff) make a few suggestions for practising critical and oppositional reading, listening

and viewing that work well in the Afrikaans classroom. Role playing such as placing a student in a position where his/her Afrikaans is responded to in English, offers practice in acceptable ways of resisting. Students are encouraged to report on TV interviews where they have observed power relations at work through interviewing the Afrikaans speaker in English and vice versa. Selected discourse such as the letters quoted in this paper are re-written from alternative subject positions.

\section{CONCLUSION}

Students in general have reacted favourably to the introduction of a CLA component in their Afrikaans studies. They have been interested in and enthusiastic about the alternative perspectives offered by teaching Afrikaans as emancipatory discourse. All the teachers involved have reported experiencing a remarkable improvement in attitude towards Afrikaans. It is notoriously difficult to evaluate the influence of a single factor on attitude, and at this stage no empirical studies have been carried out to substantiate the claim that teaching Afrikaans as emancipatory discourse does in fact result in improved attitudes.

Should this perception be borne out by fact, Afrikaans can only berefit. Janks and Ivanic (1992:317) state that "There is a time when the struggle is at its height, and every individual choice helps to shape the future possibilities for others". This ties in well with the observation by Steyn (1984:21) that the market value of Afrikaans is increased by anyone who uses Afrikaans in any place, from the shop on the corner to contact with the 
municipality. Having said this, the irony of writing this paper in English must be addressed by refering to Janks and Ivanic (1992:318):

"Any good communicative language teaching will show learners how to conform to the conventions. CLA additionally helps people to conform with open eyes, to identify their feelings about it, and to recognize the compromises they are making" 


\section{ENDNOTES}

1. Used throughout this paper as a blanket term for any language that is not the speaker"s first language.

2. These students are the product of an educational dispensation which included the enforced teaching of Afrikaans at school and obligatory instruction through medium of Afrikaans at certain levels.

3. Personal experience and personal communication with senior teachers of Afrikaans as a second language throughout Natal/KwaZulu.

4. Interestingly enough, informal surveys done at the University of Natal (Durban) indicate that these attitudes are not necessarily linked to political antagonism. Speculation about possible causes falls outside the scope of this paper. There are indications that what Lydia Lijkendijk (Die Burger, 15 Febr. 1993) calls "... een misplaatst superieuriteitsgevoel van Engelse zijde, stammend uit de tijd dat 'Brittania rules the world'..." could be a factor.

5. A more detailed discussion of the reasons for this negativism falls outside the scope of this paper.

6. Cf. Larser-Freeman and Long (1992:176ff,) for relevant references.

7. The term critical linguistics refers to an approach in linguistics in which studies in language ecology form the framework for active resistance to institutionalized forms of discrimination against groups as well as individuals.

8. Cf. Doughty et al (1971), Hawkins (1984), James and Garrett (1991), NCLE (1985) and DES (1988/89).

9. Based on the work of Bolinger (1980) and Lakoff \& Johnson (1980).

10. A major Afrikaans moming newspaper in the Cape. 


\section{REFERENCES}

Bolinger, D. 1980. Language: the Loaded Weapon. London: Longman.

Department of Education and Science (DES). 1988. Report of the committee of inquiry into the teaching of English language. (Kingman Report) HMSO

Department of Education and Science (DES). 1989. English for ages 5 to 16. (Cox Report) HMSO

Doughty, P., Pearce, J. and Thomton, G. 1971. Language in use. London: Edward Arnold.

Fairclough, N. (ed) 1992. Critical language awareness. London: Longman.

Hawkins, E. 1984. Awareness of language: an introduction. Cambridge: Cambridge University Press.

James, C. and Garrett, P. 1991. Language awareness in the classroom. London: Longman.

Janks, H. and Ivanic, R. 1992. Critical language awareness and emancipatory discourse. In Fairclough, N. (ed): 305-331.

Lakoff, $G$. and Johnson, M. Metaphors we live by. Chicago: University of Chicago Press.

Lancaster, L. and Taylor, R. 1992. Critical approaches to language, learning and pedagogy: a case study. In Fairclough, N. (ed): 256-284.

Larsen-Freeman, D. and Long, M.H. 1992. 2nd impresssion. An introduction to second language acquisition research. London: Longman.

Le Mahieu, J. 1984. The differential effect of attitudes and motivation on competence and control in second language acquisition. Interlanguage Studies Bulletin 8: 24-57.

McKenzie, M. 1992. "What I've always known but never been told": euphemisms, school discourse and empowerment. In Fairclough, N. (ed): 223-237. 
National Congress on Languages in Education (NCLE) 1985. Language A wareness. CILT. Prinsloo, K. en Van Rensburg, M.C.J. (reds.) 1984. Afrikaans: Stand, Taak, Toekoms. Pretoria: HAUM Opvoedkundige Uitgewery.

Steyn, J. 1984. Die oorlewing van Afrikaans, In Prinsloo, K. en Van Rensburg, M.C.J. (reds.): $3-29$. 